\title{
Ethanol Extract of Spondias pinnata Leaves Reduce Parasite Number and Increase Macrophage Phagocytosis Capacity of Mice Infected by Plasmodium berghei
}

\author{
Dewa Ayu Agus Sri Laksemi ${ }^{1, *}$, I Gusti Kamasan Arijana ${ }^{2}$, I Made Sudarmaja ${ }^{1}$, \\ Ni Luh Ariwati ${ }^{1}$, Ketut Tunas ${ }^{3}$, Putu Ayu Asri Damayanti ${ }^{1}$, Ni Luh Putu Eka Diarthini ${ }^{1}$, \\ I Kadek Swastika ${ }^{1}$, Ida Ayu Dewi Wiryantini ${ }^{4}$ \\ 'Department of Parasitology, Faculty of Medicine, Universitas Udayana, Jl. PB Sudirman, Denpasar, Bali, Indonesia \\ ${ }^{2}$ Department of Histology, Faculty of Medicine, Universitas Udayana, Jl. PB Sudirman, Denpasar, Bali, Indonesia \\ ${ }^{3}$ Management of Health Information Department, Bali Internasional University, Jl. Seroja, Gang Jeruk, Denpasar, Bali, Indonesia \\ ${ }^{4}$ Department of Biochemistry, Faculty of Medicine, Universitas Udayana, Jl. PB Sudirman, Denpasar, Bali, Indonesia \\ *Corresponding author. E-mail: srilaksemi@unud.ac.id
}

Received date: May 31, 2020; Revised date: Nov 12, 2020; Accepted date: Nov 13, 2020

\section{Abstract}

$\mathrm{B}$ ACKGROUND: Currently, there is no vaccine against malaria in humans, the development of resistance to anti-malarial drugs, causing the need to find new alternatives to overcome malaria infections. This study aimed to determine effect of Spondias pinnata in increasing cellular immunity, especially phagocytosis activity of peritoneal macrophages against Plasmodium berghei infection.

METHODS: This was an experimental study with two stages of research, each stage requires $36 \mathrm{Balb} / \mathrm{c}$ mice, aged 2 months and weight 20-25 grams. After one week of acclimatization, the mice were put into 6 different groups, each group consisted of 6 mice. The negative control was a group of mice given distilled water for 14 days then infected by $P$. berghei in the $15^{\text {th }}$ day. Meanwhile, T1, T2, T3, T4 and T5 groups were given $S$. pinnata leaves ethanol extract with dose of 25, 50,100, 200 and $400 \mathrm{mg} / \mathrm{kg}$ body weight
(BW)/day, respectively, and then infected by $P$. berghei in the $15^{\text {th }}$ day.

RESULTS: The results showed that the lowest parasitemia and the highest capacity of macrophage to phagocytose latex was found in treatment group T3 that received $50 \mathrm{mg} / \mathrm{kg} \mathrm{BW}$ of $S$. pinnata leaves ethanol extract. Based on analysis of the Pearson correlation test, there was a significant correlation between percent phagocytosis and parasitemia $(p<0.05)$.

CONCLUSION: Ethanol extract of $S$. pinnata leaves lower the parasite number of $P$. berghei in Balb/c mice and increase the capacity of macrophage to phagocytose latex. However, the mechanisms of how S. pinnata leaves extract in activating phagocytosis capacity and reducing parasitemia still need further investigation.

KEYWORDS: phagocytosis, Plasmodium berghei, parasite number, Spondias pinnata

Indones Biomed J. 2021; 13(1): 40-7

\section{Introduction}

Malaria is the biggest health problem in the world besides HIV/AIDS and tuberculosis. Malaria is the worst infectious disease in the world, especially fatal if caused by the Plasmodium falciparum infection.(1,2) Based on World Health Organization (WHO) data in 2018, it was found that around 228 million people were infected by malaria with a death toll of $405,000,67 \%$ of this number were children aged less than 5 years.(3-7)

Problems encountered in malaria include a complex life cycle consisting of various stages of parasite, the unavailability of vaccines, and anti-malaria drug resistance. (8) Currently, the best treatment for uncomplicated malaria worldwide is using artemisinin combination therapies 
(ACTs), but since 2017, partial resistance to artemisinins has been reported in several regions. The occurrence of malaria drug resistance threatens the effectiveness of existing malaria therapy, malaria control program and malaria elimination efforts.(9) The threat of parasitic strains that are resistant to currently available drugs, encourages efforts to find new regimens and new strategies for using existing anti-malarial drugs, and the development of new compounds that are ready to be used as anti-malarials.(8)

Plants and herbs are currently being developed to provide an affordable treatment option for various health problems.(10) There were 877 new drugs produced from $1981-2002$, 6\% came from natural products, $27 \%$ derived from natural products, $16 \%$ came from synthetic materials developed from natural materials.(11)

Malaria drugs such as quinine, artemisin, atovaquone come from plants. Quinine comes from the plant species Cinchona (Rubiaceae), artemisin, which is currently used as the most effective malaria therapy comes from Artemisin annua (Asteraceae), while atovaquone which is the latest malaria treatment comes from the Talebuia impetiginosa plant.(12) There are many plants in Indonesia that are used as traditional malaria medicine. Andrographis paniculata, Azadirachta indica, Cassia siamea, Alstonia scholaris, Jasminum quenquenerium, Swietenia macrophylla, Phylanthus niruri, Artocarpus champeden are examples of plants used traditionally as anti-malarial drugs. Bark extract of Strychnos ligustrina was able to inhibit Plasmodium berghei in vivo.(12) A local herb that also been used traditionally as anti-malarial drugs Croton caudatus Geiseler (CCG).(10)

Spondias pinnata are medium-sized deciduous trees with imparipinnate leaves, polygamous flowers and ovoid greenish-yellow fruits.(13) Genus Spondias plant consists of many species, thus used as traditional medicine to treat various diseases. Plant parts of the genus Spondias from skin, roots, fruit, leaves have various benefits and have been used as traditional medicine in various countries.(14) Ethanol extract of $S$. pinnata contain terpenoid, polyphenols and flavonoids.(13) A study shows Brassica nigra, which contains components of alkaloids, flavonoids, tannins, terpenoids such as those of $S$. pinnata, have an effect on $P$. berghei infection.(15)

Other research reported that water extracts from the skin of $S$. pinnata are safe up to $2 \mathrm{~g} / \mathrm{kg} \mathrm{BW}$ of Wistar rats. The administration of the extract for 28 days did not cause changes in general conditions, appetite, body weight, growth, biochemical parameters, hematological values and histopathological abnormalities in body tissue.(15)
Research using S. pinnata in malaria infections has never been studied.

There has never been a study using $S$. pinnata extract on $P$. berghei infection. S. pinnata has never been used traditionally to treat malaria, therefore this study was conducted to determine the immunostimulant effect of $S$. pinnata on $P$ berghei infection in mice. Other research showed that administration of $S$. pinnata at a dose of less than $1 \mathrm{~g} / \mathrm{kg}$ BW was toxicologically safe (13), thus we decided to use range dosage from $1 \mathrm{mg} / \mathrm{BW}$ to $1 \mathrm{~g} / \mathrm{BW}$. Based on the background above, we conducted a study to investigate the immunostimulant effect of 25, 50,100, 200 and $400 \mathrm{mg} / \mathrm{Kg} \mathrm{BW} \mathrm{S}$. pinnata extract on parasitemia and the ability of macrophages to phagocytose latex in mice infected with $P$. berghei.

\section{Methods}

The treatment of animals models were conducted at the experimental animal of Integrated Biomedic Laboratory, Faculty of Medicine, Universitas Udayana. Macrophage culture was conducted at the Histology Laboratory, Faculty of Medicine, Universitas Udayana. The P. berghei used in this study was obtained from Department of Parasitology, Faculty of Medicine, Universitas Gadjah Mada. The ethical clearance was obtained from the Ethics Committee, Faculty of Medicine, Universitas Udayana (No. 2019.03.1.0985).

\section{Plant Material and Preparation of Extract}

S. pinnata leaves used in this study came from the same plantation in Penglipuran Bangli and was determined in the Faculty of Agriculture, Universitas Udayana. The S. pinnata extraction process was carried out in accordance to standard procedures at the Food Analysis Laboratory of the Faculty of Agriculture, Universitas Udayana. Procedure for maceration started by approximately 200 grams of $S$. pinnata powder macerated with $1.5 \mathrm{~L} 80 \%$ ethanol at room temperature for 2 days, then filtered. Then the pulp was macerated with $500 \mathrm{~mL} 80 \%$ ethanol at room temperature for 2 days, then the filtrate was collected. The filtrate was concentrated by means of a rotary evaporator at $50^{\circ} \mathrm{C}$ to obtain an extract that still contains a small volume of solvent. Evaporation of the extraction solvent was continued using an oven at $40^{\circ} \mathrm{C}$ until a thick extract was obtained.(16)

\section{Animal Experimental}

This research was consisted of two stages of research. The first stage investigated the effect of $S$. pinnata on 
parasitemia, while the second stage investigated the effect of $S$. pinnata on the ability of macrophages to phagocytose latex. Each stage requires $36 \mathrm{Balb} / \mathrm{c}$ mice originated from mice bred in the experimental animal division of the Integrated Biomedical Laboratory, Faculty of Medicine, Universitas Udayana, aged 2 months and weighed 20-25 grams, were divided into 6 groups, each group consisted of 6 rats. Animals were kept in a standard room for animal studies (temperature $22-25^{\circ} \mathrm{C}$ and $12 \mathrm{~h}$ dark-light cycle). All animals got standard feed and ad libitum access to tap water. After one week of acclimatization. We divided the mice into six groups, namely negative control (NC), and treatement groups (T1-T5). NC was a group of mice given distilled water for 14 days and then infected by $P$. berghei. The mice were infected by injecting $0.2 \mathrm{~mL}$ of inoculum containing $1 \times 10^{8}$ parasite erythrocytic stage on the $15^{\text {th }}$ day. Parasitemia was observed on the $4^{\text {th }}$ day by dissecting 6 mice from first stage groups, while peritoneal macrophages were isolated from second stage group on the $5^{\text {th }}$ day.(17) T1, T2, T3, $\mathrm{T} 4$ and T5 were given leaves ethanol extract of $S$. pinnata dose at 25, 50, 100, 200 and $400 \mathrm{mg} / \mathrm{kg}$ body weight (BW)/ day, respectively, then were infected by $P$. berghei in the $15^{\text {th }}$ day. $S$. pinnata leaves extract were administered orally using a 12-gauge sonde in a 24-hour cycle. This study was to determine the immunostimulant effect of $S$. pinnata on $P$. berghei infection in mice, thus $S$. pinnata extract was given for 14 days before mice were infected with P. berghei.

\section{Hematological Examination and Parasitemia}

Hematological examination and parasitemia were carried out on the $4^{\text {th }}$ day after the mice were infected with $P$. berghei. Hematological examination was done until parasitemia reached $5-10 \%$. Blood thin preparation was done using blood from tail of mice, then placed on the tip of the microscope slide. After the dry smear was fixed with methanol and stained with Giemsa $10 \%$ for 15 minutes, then washed with running water, after drying the blood smear was examined to count parasitemia by microscope 1000x magnification with immersion oil. Parasitemia was described the density of blood cells infected by parasites in erythrocytes. Calculation parasitemia was done manually by calculating the percentage of the number of erythrocytes with $P$. berghei in 1000 erythrocytes.(17) The examination was done by a trained analyst, with blinding examination to prevent bias.

\section{Isolation and Culture of Peritoneal Macrophage Cell}

Mice were sacrificed by cervical dislocation on day $6^{\text {th }}$ to start the procedure of isolation and culture of peritoneal macrophage cell. Mice were placed in the supine position, the skin of the abdomen was opened and peritoneal sheath was cleaned by $70 \%$ alcohol. Then $\pm 3 \mathrm{~mL}$ of cold Roswell Park Memorial Institute (RPMI) media was injected into the peritoneal cavity, wait for \pm 3 minutes to pat the abdomen gently. Peritoneal fluid was removed from the peritoneal cavity by aspirated the fluid with a syringe, especially in a non-fatty part and away from the intestine. The needle containing aspiration material was placed in a beaker filled with ice, then the suspension is inserted into the centrifuge tube. Aspirate is centrifuged at $1,200 \mathrm{rpm}, 4^{\circ} \mathrm{C}$ for 10 minutes. The supernatant is removed, then added $1 \mathrm{~mL}$ of complete medium to the obtained pellet. The number of cells was counted with a hemocytometer and the viability determined with trypan blue was then resuspended with complete RPMI medium thus cell suspension with a density of $2.5 \times 10^{6} / \mathrm{mL}$ was obtained.(17)

The calculated cell suspension was cultured on 24 microplate wells that had been given a round slips cover, each well was $200 \mu \mathrm{L}\left(5 \times 10^{5}\right.$ cells). Incubated in a $5 \% \mathrm{CO}_{2}$ incubator, $37^{\circ} \mathrm{C}$ for 60 minutes. Then added a complete medium of $1 \mathrm{~mL}$ RPMI per wells and incubated again for 4 hours. Cells were washed with RPMI $2 \mathrm{X}$ then added $1 \mathrm{~mL}$ complete medium per well and continued incubation for 24 hours. Macrophage cells were ready to be tested for their activity.(17)

\section{Latex Phagocytosis Activity}

To determine the activity of $S$. pinnata as an stimulant of cellular immunity in $P$. berghei infection, the phagocytosis assay test was carried out in this study. Latex phagocytosis activity test procedure through the calculation of latex particles using latex beads diameter of $3 \mu \mathrm{m}$. Latex beads are resuspended in PBS to obtain a concentration of $2.5 \times 10^{7} / \mathrm{mL}$. Macrophages that were cultured the day before were washed twice with RPMI. The latex suspension was added $200 \mu \mathrm{L}\left(5 \times 10^{6}\right) /$ well or latex density in $1 \mathrm{~mL}$ was $2.5 \times 10^{7}$, and incubated in a $5 \% \mathrm{CO}_{2}$ incubator at $37^{\circ} \mathrm{C}$ for 60 minutes. The cell was then washed with phosphate buffered saline (PBS) three times to remove particles that were not phagocytosed, dried at room temperature, and fixed with absolute methanol for 30 seconds. Then the methanol was discarded, and wait for it to dry.

After drying, coverslips were daubed with Giemsa $10 \%$ for 15 minutes. The percentage of cells that phagocytose latex particles and the number of latex particles that were phagocytosed were counted from 100 cells examined under a light microscope with a magnification of 400x. From each subject examined, 3 slides were made.(18) 


\section{Statistical Analysis}

Data processing was performed using IBM Statistical Package for Social Sciences for Windows (SPSS) version 23.0 (IBM Coorporation, Armonk, NY, USA), with $p<0.05$ was significance. Parasitemia ( $\mathrm{P})$ and Percentage of Phagocytosis (PP) were compared using analysis of variance followed by Tukey Honest Significant Difference (HSD) test.

\section{Results}

Six groups of mice with an average weight of 20-25 g were used in this study. The six groups were compared in terms of age, and body weight, parasitemia, percentage of phagocytosis. Data were expressed as mean $\pm \mathrm{SD}$ of six replications. The distribution of body weight between the six groups at baseline was similar.

In the T1-T5 treatment group there were a significant decrease of parasitemia, i.e., the number of erythrocytes infected with P. berghei and also a significant increase of the percentage of peritoneal macrophages that phagocytosis of latex particles when compared with the control group (NC) $p<0.05$ (Table 1).

Furthermore, from the One Way Anova analysis and the Tukey Honest Significant Difference test, we found significant differences in parasitemia and the percentage of phagocytosis between the treatment and control groups $(p<0.05)$ (Table 1). Based on the analysis of the Pearson correlation test, it was found that there was a significant correlation between percent phagocytosis and parasitemia $(p<0.05)$.

The ethanol extract of $S$. pinnata leaves with the highest efficacy in reducing parasitemia was found in the $\mathrm{T} 2$ group who received $50 \mathrm{mg} / \mathrm{kg} /$ day for 14 days (Figure 1). The phagocytic ability of macrophages appears to be improved by the administration of S.pinnata ethanol extract, especially in the T1 and T2 groups who received S.pinnata ethanol extract at doses of 25 and $50 \mathrm{mg} / \mathrm{kg} /$ day for 14 days. This study was found that the higher the percentage of latex phagocytosis macrophages, the lower the parasitemia (Figure 1).

Erythrocyte infected with $P$. berghei with Giemsa staining and 400x magnification were indicated by ring form inside the erythrocyte cytoplasm (Figure 2). The highest erythrocytes infected with $P$. berghei was found in the control group without administration of ethanol extract of S. pinnata leaves (Figure 2).

Macrophage phagocytosis test with the calculation of latex particles using cultured macrophage cells. Macrophages were the main phagocytic cells that fight invasion of pathogens such as bacteria, parasites and viruses through the mechanism of phagocytosis. The ability of macrophage phagocytosis can be measured by its ability to phagocytose latex particles in vitro. Macrophages that phagocytose latex were characterized by latex particles attached to the surface of the macrophage or inside the macrophage (Figure 3). The ability of these macrophages appeared to be increased in the group receiving ethanol extract of $S$. pinnata leaves compared to the control group (Table 1).

\section{Discussion}

The results of this study indicate that the ethanol extract of S.pinnata has the effect of reducing parasitemia. In this study, the effect of weight on parasitemia was controlled because the weight of the mice did not differ significantly. The results of this study indicate that the ethanol extract of S.pinnata has the effect of increasing the phagocytosis activity of macrophages as measured by its ability to phagocytose latex particles. Factors that affect the phagocytic activity of macrophages are cytokines, chemokines, plasmodium species, strains and serotypes.

Table 1. Mean values and standard deviation obtained within the computer-assisted analysis of mice infected by $P$. berghei after treated with $S$. pinnata leaves extract.

\begin{tabular}{|c|c|c|c|c|c|c|c|}
\hline \multirow{2}{*}{ Characteristics } & \multicolumn{6}{|c|}{ Group $(n=6)$} & \multirow{2}{*}{$p$-value } \\
\hline & NC & T1 & $\mathbf{T} 2$ & T3 & $\mathbf{T 4}$ & T5 & \\
\hline W0 & $23.3 \pm 1.9$ & $24.7 \pm 0.5$ & $23.2 \pm 2.2$ & $23.8 \pm 2$ & $22.5 \pm 2.7$ & $23.7 \pm 2.3$ & 0.604 \\
\hline W1 & $27.2 \pm 1$ & $26.3 \pm 3.3$ & $26.2 \pm 4.7$ & $23.8 \pm 5.5$ & $24.7 \pm 4.1$ & $29.3 \pm 5.6$ & 0.33 \\
\hline Phagocytosis (\%) & $1.2 \pm 0.4$ & $14.3 \pm 1$ & $34.3 \pm 1$ & $8.7 \pm 0.8$ & $10.5 \pm 5$ & $12.5 \pm 1$ & 0 \\
\hline Parasitemia & $10.9 \pm 2$ & $2.9 \pm 1.5$ & $2.5 \pm 0.7$ & $4.7 \pm 0.6$ & $4.2 \pm 1$ & $5.30 \pm 4$ & 0 \\
\hline
\end{tabular}

W0: weight before administration of ethanol leaves extract of S. pinnata; W1: weight after administration of ethanol leaves extract of $S$. pinnata. $p$-value was tested with One Way Anova, $p \leq 0.05$ is statistically significant difference. 


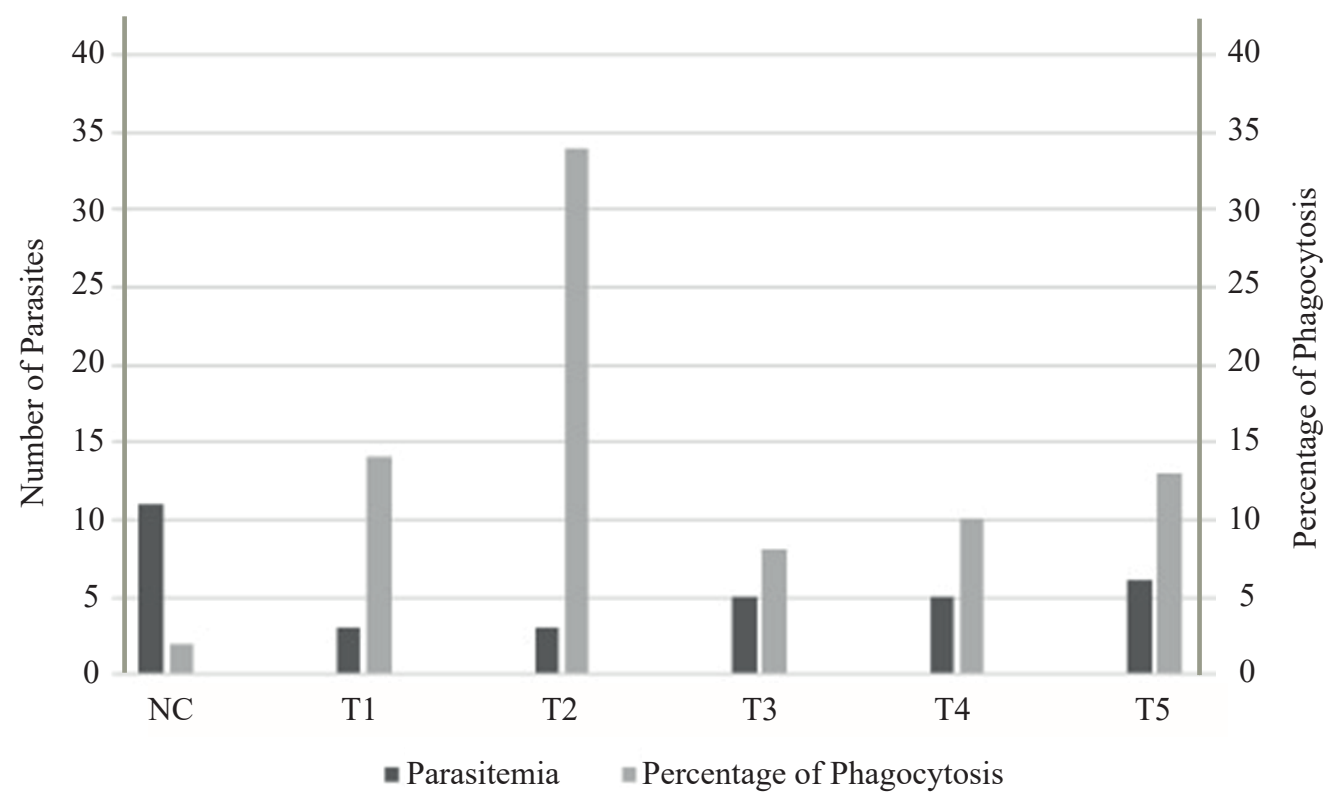

Figure 1. Relation between parasitemia and phagocytosis activity of peritoneal macrophage of mice infected by $P$. berghei after 14 days of $S$. pinnata leaves extract administration.
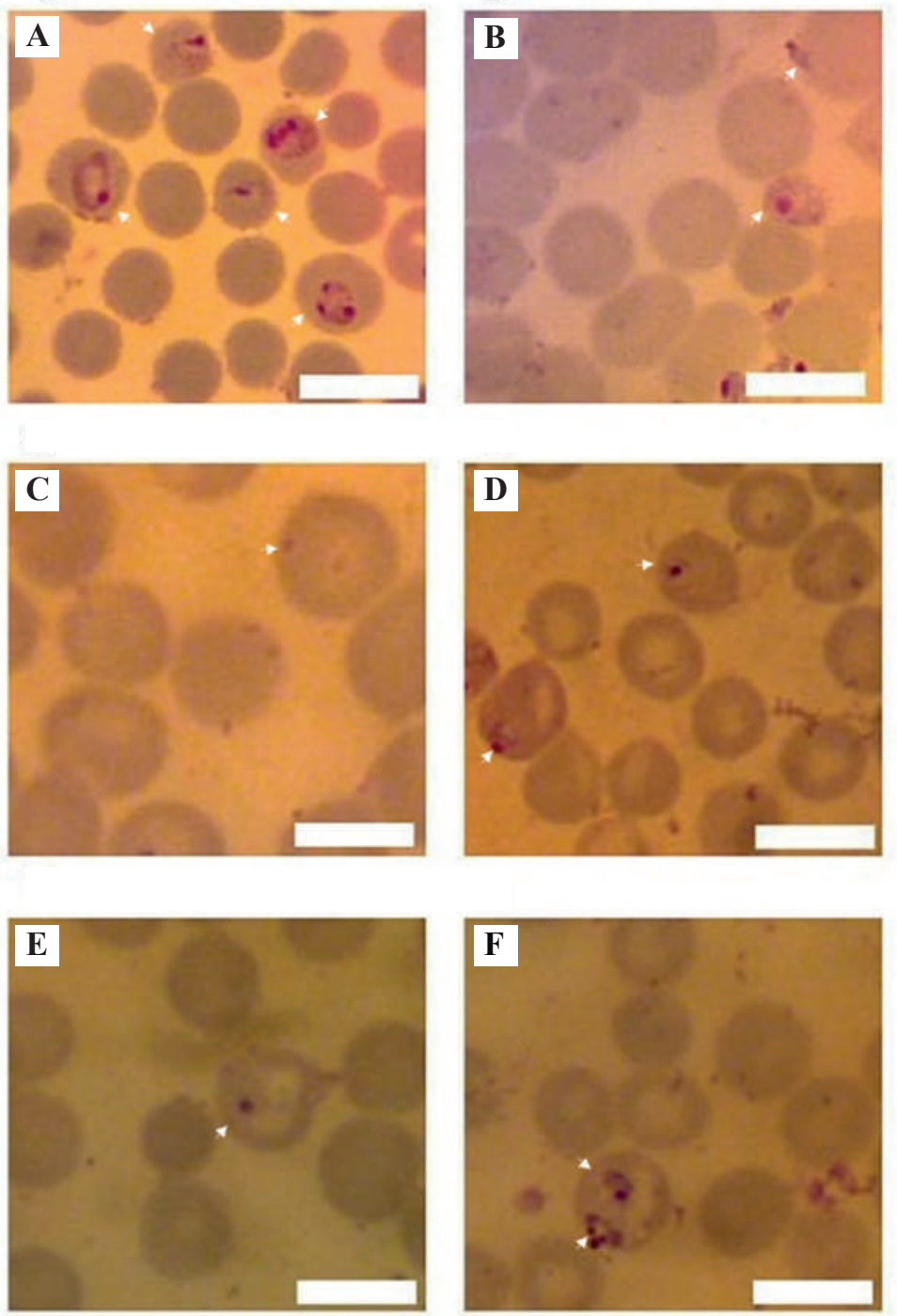

Figure 2. Morphology of erythrocyte infected by P. berghei. A: NC; B: T1; C: T2; D: T3; E: T4; F: T5. Cell in passage were documented under an upright light microscope using Giemsa Staining. White bar: $10 \mu \mathrm{m}$. White arrow: ring formation inside the erythrocyte cytoplasm. 

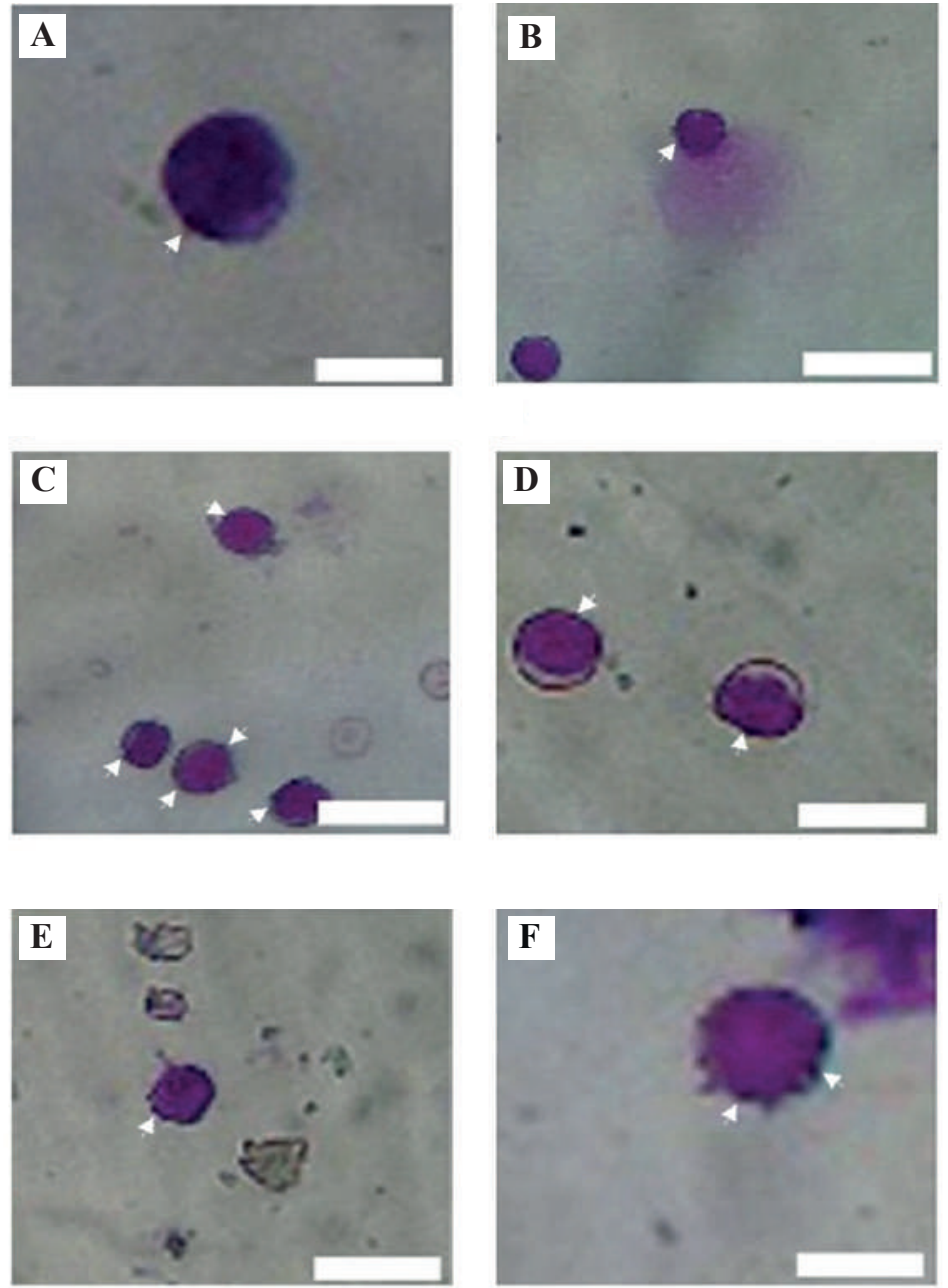

Figure 3. Morphology of Macrophage derived from peritoneal cavity of mice $\mathrm{A}$ : $\mathrm{NC}$; $\mathrm{B}: \mathrm{T} 1$; C: T2; D: T3; E: T4; F: T5. Cell in passage were documented under an inverted light microscope using Giemsa Staining. White bar: $10 \mu \mathrm{m}$. White arrow: latex particles attached to the surface of the macrophage.
(17-19) Dysregulation cytokine and chemokine affect the function of macrophages as an effector on the natural immune system.(17,20) However, in this study the mechanism that causes phagocytic activity of macrophages increased and parasitemia decreased due to the administration of $S$. pinnata leaves ethanol extract had not established.

$P$. berghei is species that caused lethal malaria in mice. Phagocytosis by macrophages was varied depend on species and serotype of Plasmodium. Differences in plasmodium species giving rise to different capacities to induce the production of $\mathrm{O}_{2}$ metabolites by macrophages, thus affecting the final course of the disease.(21) Leaves of $S$. pinnata contain flavonoids, tannins, gums, alkaloids, saponins and terpenoids. It has mentioned in previous research that phenolic and flavonoid content is equivalent to gallic acid and quercetin.(22)

Various studies have shown that in the physiopathogenesis of malaria, free radicals are formed through oxidative stress. $(21,23,24)$ The discovery of high concentrations of plasma malondialdehyde which is a byproduct of lipid peroxidase is evidence that the level of oxidative stress in malaria increases. Plasmodium infection will trigger gamma interferon-producing Th1 cells, which causes activated macrophages to produce nitric oxide (NO) and reactive oxygen species (ROS) which can kill parasites.(25) However, ROS and oxidative stress cause pathologies of malaria infection, also contribute to complication of malaria.(21,23-25) Antioxidants have been shown to reduce the negative effects of oxidative stress, including ROS, which occurs in malaria infection. $(24,26,27)$

The increase in cellular immune response found in this study hypothetically could be due to the content of terpenoids and flavonoids found in the ethanol extract of $S$. pinnata leaves. Previous research mentioned $S$. pinnata leaves contain high phenol and flavonoid components. Other parts of the plant such as fruit are also a large source of energy. S. pinnata has an antioxidant effect.(22) In this study, there was a slight decrease in cellular immune response in mice that received ethanol extract $S$. pinnata at doses of 100, 200 and $400 \mathrm{mg} / \mathrm{kg} \mathrm{BW}$ /day compared to those who received 25 and $50 \mathrm{mg} / \mathrm{kg} \mathrm{BW} /$ day. However, the 
cellular immune response was still higher than the group that only received distilled water (NC).

There has never been a study that tested $S$. pinnata in plasmodium infections. However, there have been studies using bark extract of $S$. pinnata in helminths namely Pheretima postuma, an Indian earth worm.(28) The results of this study are in line with other studies that found antituberculosis extract activity at a concentration of 50 $\mathrm{mg} / \mathrm{mL}$. That research showed that methanol extract of $S$. pinnata leaves contained triterpenoids and flavonoids.(29)

Flavonoids has immunostimulatory effect, may be due to cell mediated and humoral antibody mediated immune response.(30) There was an review regarding biological role of flavonoids and terpenoids in the treatment of parasite namely leishmaniasis. Flavonoids and terpenoids are major secondary metabolite used in the treatment of leishmaniasis by producing therapeutic efficacy against visceral leishmaniasis. Their potential is equivalent to the leishmaniasis drugs on the market.(30) Our study were not excluding the impact of the used solvent in extraction process. Some factors that might influence the increase of phagocytic activity of peritoneal macrophages thus reducing the density of $P$. bergei parasites due to administration of $S$. pinnata leaves ethanol extract also has not been determined so far.

\section{Conclusion}

Ethanol extract of $S$. pinnata leaves lower the parasite number of $P$. berghei in Balb/c mice and increase the capacity of macrophage to phagocytose latex. The ethanol extract of $S$. pinnata leaves with the highest efficacy in reducing parasitemia and phagocytic ability was found in the T2 group which received $50 \mathrm{mg} / \mathrm{kg} / \mathrm{day}$ for 14 days. Based on the analysis of the Pearson correlation test it was found that there was a significant correlation between percent phagocytosis and parasitemia.

\section{Acknowledgements}

The authors wish to express their gratitude to Universitas Udayana's Chancellor and the Dean of The Faculty of Medicine, Universitas Udayana for supporting and encouraging this paper to be published. The authors also would like to thank to Institute for Research and Community Services, Universitas Udayana that have funded this research through Universitas Udayana Flagship Research
Grant Year 2019. The authors also appreciate Made Angga Baskara, Ni Kadek Devi Antari and Ni Made Yethi Agustini for their kind assistance in laboratory works.

\section{Authors Contribution}

SL involved in concepting and planning the research, KA, $\mathrm{AD}$ and $\mathrm{ED}$ performed the data acquisition/collection and result interpretation, $\mathrm{KT}$ and MS calculated the experimental data and performed the analysis, DW drafted the manuscript and designed the figures, LA and KS aided in interpreting the results. All authors took parts in giving critical revision of the manuscript.

\section{References}

1. Ogbole EA, Ogbole Y, Peter JY, Builders MI, Aguiyi JC. Phytochemical screening and in vivo antiplasmodial sensitivity study of locally cultivated Artemisia annua leaf extract against Plasmodium berghei. Ame J Ethnomed. 2014; 1: 42-9.

2. Talapko J, Škrlec I, Alebi'c T, Juki'c M, V`cev A . Malaria: The past and the present. Microorganisms. 2019; 7: 179. doi: 10.3390/ microorganisms 7060179 .

3. Aguilar JB, Gutierrez JB. An epidemiological model of malaria accounting for asymptomatic carriers. Bull Math Biol. 2020; 82: e42. doi: 10.1007/s11538-020-00717-y.

4. Zekar L, Sharman T. Plasmodium Falciparum Malaria. In: StatPearls [Internet]. Treasure Island (FL): StatPearls Publishing; 2020.

5. Chanda-Kapata P, Kapata N, Zumla A. COVID-19 and malaria: A symptom screening challenge for malaria endemic countries. Int $\mathrm{J}$ Infect Dis, 2020; 94: 151-3.

6. Rogerson SJ, Beeson JG, Laman M, Poespoprodjo JR, William T, Simpson JA, et al. Identifying and combating the impacts of COVID-19 on malaria. BMC Med. 2020; 18: 239. doi: 10.1186/ s12916-020-01710-x.

7. Nghochuzie NN, Olwal CO, Udoakang AJ, Amenga-Etego LN, Amambua-Ngwa A. Pausing the fight against malaria to combat the COVID-19 pandemic in Africa: is the future of malaria bleak? Front Microbiol. 2020; 11: 1476. doi: 10.3389/fmicb.2020.01476.

8. Arama C, Troye-Blomberg M. The path of malaria vaccine development: challenges and perspectives. J Internal Med. 2014; 275: 456-66.

9. Menard D, Dondorp A. Antimalarial drug resistance: A threat to malaria elimination. Cold Spring Harb Perspect Med. 2017; 7 : a025619. doi: 10.1101/cshperspect.a025619.

10. Dasiman R, Malek MA, Bahari EA, Zakaria FN, Hashim NK, Samsudin A, et al. Effect of Croton caudatus Geiseler aqueous root extract on reproductive and biochemical parameters in male wistar rats. Indones Biomed J. 2020; 12: 251-60.

11. Silva JR, Ramos Ade S, Machado M, de Moura DF, Neto Z, CantoCavalheiro MM, et al. A review of antimalarial plants used in traditional medicine in communities in Portuguese-speaking countries: Brazil, Mozambique, Cape Verde, Guinea-Bissau, São Tomé and Príncipe and Angola. Mem Inst Oswaldo Cruz. 2011; 106: $142-58$. 
12. Taek MM, Prajogo B, Agil M. Plants used in traditional medicine for treatment of malaria by Tetun ethnic people in West Timor Indonesia. Asian Pacific J Trop Med. 2018; 11: 630-7.

13. Jain P, Hossain KR, Mishu TR, Reza HM. Antioxidant and antibacterial activities of Spondias pinnata Kurz. leaves. European J Med Plants. 2014; 4: 183-95.

14. Sameh S, Al-sayed E, Labib RM, Singab AN. Genus Spondias : A phytochemical and pharmacological review. Evid Based Complement Alternat Med. 2018; 4: 5382904. doi: $10.1155 / 2018 / 5382904$.

15. Attanayake AP, Jayatilaka KAPW, Pathirana C, Mudduwa LKB. Toxicological investigation of Spondias pinnata (Linn . F.) Kurz. (Family: Anacardiaceae) bark extract in Wistar rats. Inter. J Pharmacog. 2015; 9: 26-31.

16. Padmasari PD, Astuti KW, Warditiani NK. Skrining fitokimia ekstrak etanol 70\% Rimpang Bangle (Zingiber purpureum Roxb.). Jurnal Farmasi Udayana. 2013; 2013: 1-7.

17. Wijayanti MA. Kemampuan fagositosis makrofag peritoneum mencit yang diimunisasi selama infeksi Plasmodium berghei. Berkala Ilmu Kedokteran. 1999; 31: 213-8.

18. Hirayama $D$, Iida $T$, Nakase $H$. The phagocytic function of macrophage-enforcing innate immunity and tissue homeostasis. Int J Mol Sci. 2017; 19: 92. doi: 10.3390/ijms19010092.

19. Thakre N, Fernandes P, Mueller AK, Graw F. Examining the reticulocyte preference of two Plasmodium berghei strains during blood-stage malaria infection. Front Microbiol. 2018; 9: 166. doi: 10.3389/fmicb.2018.00166.

20. Arango Duque G, Descoteaux A. Macrophage cytokines: involvement in immunity and infectious diseases. Front Immunol. 2014; 5: 491. doi: $10.3389 /$ fimmu.2014.00491.
21. Percário S, Moreira DR, Gomes BA, Ferreira MES, Gonçalves ACM, Laurindo PSOC, et al. Oxidative stress in malaria. Int J Mol Sci. 2012; 13: 16346-72.

22. Laksemi DAS. Biological activity of Spondias pinnata: a review. Indones J Biomed Sci. 2019; 13: 88-93.

23. Aitken EH, Alemu A, Rogerson SJ. Neutrophils and malaria. Front Immunol. 2018; 9: 3005. doi: 10.3389/fimmu.2018.03005.

24. Isah MB, Ibrahim MA. The role of antioxidants treatment on the pathogenesis of malarial infections: a review. Parasitol Res. 2014; 113: 801-9.

25. Ty MC, Zuniga M, Götz A, Kayal S, Sahu PK, Mohanty A, et al. Malaria inflammation by xanthine oxidase-produced reactive oxygen species. EMBO Mol Med. 2019; 11: e9903. doi: 10.15252 emmm.201809903

26. Yunarto N, Rossyid HM, Lienggonegoro LA. Effect of ethanolic leaves extract of Peperomia pellucida (L) Kunth as anti-malarial and antioxidant. Media Litbangkes. 2014; 28: 123-30.

27. Ngoutane A, Jiatsa CD, Yamthe LR, Tchuenmegne MA, Toghueo $\mathrm{RM}$, Tsouh PV, et al. In vitro and in vivo antiplasmodial activity of extracts from Polyalthia suaveolens, Uvaria angolensis and Monodora tenuifolia (Annonaceae). Int J Biol Chem Sci. 2017; 11: 118-30.

28. Mondal S, Dash GK, Chhetree RR. Anthelmintic activity of Spondias pinnata (Linn. F) Kurz. Res Rev J Pharmacogn Phytochem. 2010; 2: $103-8$.

29. Dwija IPB, Juniarta IK, Yowani SC, Ariantari NP. Antituberculosis activity of methanolic extract of kedondong hutan (Spondias pinnata (1.f.) kurz.) leaves. Jurnal Kimia. 2013; 7: 25-30.

30. Chandrasekar R, Debnath S, Sivagami B. Therapeutic efficacy of flavonoids and terpenoids an ongoing herbal therapy in the treatment of leishmaniasis. Nat Prod Ind J. 2018; 14: 124. 